\section{CURRÍCULO, GÊNERO E SEXUALIDADE}

Guacira Lopes Louro

Porto: Porto Editora, 2000, I I I p.

Convidada pelo Coordenador da coleção Currículo, Políticas e Práticas, da Porto Editora, de Portugal, Guacira Lopes Louro, professora de História da Educação da Universidade Federal do Rio Grande do Sul, selecionou textos que foram elaborados, em maioria, para constituir conferências ou palestras dirigidas a docentes ou especialistas em educação. Quinto volume de um total de cinco obras da coleção, a autora inicia com "Um olhar feminista sobre a educação", primeiro capítulo da obra, e continua, nos demais capítulos, a inserir o contexto da sexualidade no bojo de sua discussão sobre a diferença no currículo.

Ao partir da própria história como professora e pesquisadora, a autora abre o livro refletindo sobre os estudos de gênero da perspectiva da formação acadêmica que teve e que acabou por incitar a linha de pesquisa que desenvolve em suas palavras: "o meu encontro (com o feminismo) fez-se no âmbito acadêmico, motivado pela notável ausência das mulheres como sujeito ou como objeto da historia". Ao conceituar o gênero, Guacira rompe com a rígida polaridade binária entre masculino e feminino, passando a trabalhar com a pluralidade no interior de cada um desses pólos.

Volta-se, ainda, para as formas como as diferenças - e aí inclui diferenças sexuais, raciais, étnicas, culturais - são construídas e fixadas, questionando as maneiras como passam a ser valorizadas ou negadas pela sociedade. O entrelaçamento desses temas é marca facilmente perceptível e situa o leitor diante de uma problemática que vai além da questão de gênero e sexualidade: ser diferente de quê? E sob quais circunstâncias a perpetuação das diferenças não é a continuidade de uma veIha discussão em que as marcas - branco, classe média, heterossexual - tornaram-se o centro marginalizador dos sujeitos não integrantes dessa classificação?

No segundo capítulo: "Gênero e Magistério: representações plurais" circula o alerta para a necessidade de complexificar, ampliar e transformar as condições que têm permitido à atividade docente, especialmente quando dirigida a crianças, tornar-se feminina. Para isso, de maneira clara e abrangente, privilegiou-se o conceito de gênero não ligado ao desempenho de papéis masculinos ou femininos, mas sim ligado à produção de identidades - múltiplas e plurais - de mulheres e homens no interior de relações de poder.

Os três últimos capítulos têm o objetivo de corporificar a questão da sexualidade no currículo e alertam para a evidente simplificação que é imposta ao tema nas escolas. A dessexualização do ambiente escolar é situada em um contexto em que se pode falar do sexo e o que se deve esconder é problematizado, sendo que as verdades impostas devem passar a ser questionadas de maneira a repensar as questões que foram consagradas ou marginalizadas: "desarranjar e reinventar a história para que ela possa tornar-se plural".

Em síntese, a leitura do livro, além do bem dosado apelo teórico, encanta pela sensibilidade e pela arte percebida nas palavras, tão elegantemente dispostas pela autora. Isso torna a leitura da obra um exercício literário fascinante que vai além da discussão sobre sexualidade e gênero e alcança a dimensão de uma identidade plural: a identidade dos sujeitos.

Rodrigo Gonzalez Instituto de Ciências Biomédicas da Universidade de São Paulo rgonzale4@hotmail.com 